\title{
WIEDZA NA TEMAT RAKA JĄDRA WŚRÓD STUDENTÓW PŁCI MĘSKIEJ PAŃSTWOWEJ WYŻSZEJ SZKOŁY ZAWODOWEJ W LESZNIE
}

\section{KNOWLEDGE ABOUT TESTICULAR CANCER AMONG MALE STUDENTS OF JAN AMOS KOMEŃSKI UNIVERSITY OF APPLIED SCIENCES IN LESZNO}

\author{
Maciej Górecki \\ Instytut Zdrowia i Kultury Fizycznej, Państwowa Wyższa Szkoła Zawodowa im. Jana Amosa Komeńskiego w Lesznie \\ https://orcid.org/0000-0002-4716-0269
}

DOI: https://doi.org/10.20883/pielpol.2021.7

\section{STRESZCZENIE}

Wstęp. Do najczęściej występujących nowotworów męskich narządów płciowych zalicza się: raka jądra, raka gruczołu krokowego i raka prącia. Wśród młodych dorosłych w wieku 20-44 lat rak jądra jest najczęściej występującym nowotworem złośliwym, bo aż 25\% zachorowań dotyczy tej właśnie grupy wiekowej.

Cel. Celem niniejszej pracy było zbadanie stanu wiedzy studentów płci męskiej Państwowej Wyższej Szkoły Zawodowe im. Jana Amosa Komeńskiego w Lesznie na temat raka jądra, ponadto zwrócenie uwagi na tę chorobę i jej objawy, a także na potrzebę samobadania.

Materiał i metody. Badanie zostało przeprowadzone jednorazowo, przy użyciu kwestionariusza ankiety w formie papierowej, przekazanej do wypełnienia respondentowi. Dobór był dowolny, jedynym warunkiem była płeć męska i status studenta PWSZ w Lesznie. Kwestionariusz ankiety zawierał 11 pytań zamkniętych, na które badany mógł odpowiedzieć ,,prawda” lub „fałsz”. Wnioski. Badanie przeprowadzone wśród męskiej części studentów Państwowej Wyższej Szkoły Zawodowej im. Jana Amosa Komeńskiego w Lesznie wykazało małą wiedzę o schorzeniu, jakim jest rak jądra. Znikomy stan wiedzy studentów na temat tej choroby, tj. objawów, leczenia i prewencji, przełożył się na niski procent poprawnych odpowiedzi na niektóre pytania.

SŁOWA KLUCZOWE: rak jądra, samobadanie jąder, prewencja, urologia.

\section{Wstęp}

Do najczęściej występujących nowotworów męskich narządów płciowych zalicza się: raka jądra, raka gruczołu krokowego i raka prącia. Pod pojęciem rak jądra rozumie się grupę nowotworów, z której najczęściej diagnozuje się guzy zarodkowe (nasieniaki i nienasieniaki) oraz guzy niezarodkowe [1]. Rak jądra często rozpoznawany jest dopiero w stadium zaawansowanym, co spra-

\begin{abstract}
Introduction. The most common cancers of male genital organs include: testicular cancer, prostate cancer and penile cancer. Among young adults aged 20-44 years, testicular cancer is the most common malignant tumour, since as many as $25 \%$ of the incidence is affected by this age group.

Aim. The aim of this study was to examine the awareness of male students of Jan Amos Komeński University of Applied Sciences in Leszno on testicular cancer and in addition, to pay attention to this disease and its symptoms, as well as the need of selfexamination.

Material and methods. The study was carried out once, using a paper-form questionnaire submitted to the respondent for completion. The selection was free and the only condition was the male gender and the student status at Jan Amos Komeński University of Applied Sciences in Leszno. The questionnaire contained 11 closed questions which the respondent could answer 'true' or 'false'.

Conclusion. The survey carried out among the male students of Jan Amos Komeński University of Applied Sciences in Leszno showed low knowledge of the disease, such as testicular cancer. Little students' awareness about this disease, i. e. symptoms, treatment and prevention, resulted in a low percentage of correct answers to some questions.
\end{abstract}

KEYWORDS: testicular cancer, self-examination of the testicles, prevention, urology.

wia bardzo poważne problemy terapeutyczne i znacznie obniża szansę na wyleczenie.

Wyczulenie diagnostyczne leży nie tylko po stronie lekarza czy pielęgniarki, ale przede wszystkim po stronie każdego mężczyzny. Niestety znajomość istoty choroby wśród społeczeństwa, tj. jej pierwszych symptomów, przebiegu i możliwości wyleczenia, jest bardzo niska, co potwierdzają badania polskie i zagraniczne [2-8, 12]. 
Według Krajowego Rejestru Nowotworów nowotwory jądra stanowią ok. 1,6\% nowotworów złośliwych u mężczyzn, jednak co bardzo ważne: wśród młodych dorosłych w wieku 20-44 lat są najczęściej występującym nowotworem złośliwym, bo aż 25\% zachorowań dotyczy tej właśnie grupy wiekowej [10]. Należy zaznaczyć, iż występują dwa szczyty zachorowań: młodzieńcy i 30-kilkulatkowie oraz mężczyźni w wieku 60-75 lat. Histologicznie w pierwszej grupie wiekowej najczęściej rozpoznaje się nienasieniaki, $z$ kolei $w$ drugiej grupie wiekowej guzy mają charakter nasieniaków. Oprócz czynników związanych z wiekiem do innych podwyższających ryzyko zalicza się:

- rasę kaukaską (białą), ponieważ ci mężczyźni chorują cztery razy częściej niż mężczyźni rasy czarnej,

- wnętrostwo - wg niektórych autorów niezstąpienie jąder u chłopca zwiększa aż 17-krotnie ryzyko zachorowania,

- częste urazy okolicy moszny, np. związane z uprawianiem sportów (kolarstwo); należy zaznaczyć, iż ostatnio pojawiły się doniesienia, że sport nie ma wpływu na ten typ nowotworu) $[1,2]$.

Do dość pewnych czynników zalicza się:

- już wcześniej przebyty nowotwór jednego jądra,

- czynniki dziedziczne: przebyta choroba przez ojca czy brata powoduje 6-krotnie zwiększone ryzyko zachorowania na tę samą chorobę [1].

Do innych czynników zalicza się nieprawidłowo leczone lub niewyleczone stany zapalne jąder, które mogą zwiększyć ryzyko zachorowania na raka jądra aż 10-krotnie [1].

Jak dotąd w dostępnej literaturze zagranicznej niewielka jest liczba opracowań dotyczących wiedzy młodych mężczyzn na temat raka jądra i metod profilaktycznego samobadania [2-6], jeszcze mniej jest polskich opracowań na ten sam temat $[7,8]$. Co charakterystyczne, to zarówno w polskich jak i zagranicznych opracowaniach dominuje opinia o niskim stanie wiedzy na temat objawów, leczenia i profilaktyki raka jądra wśród młodych mężczyzn [12].

\section{Objawy}

Najważniejszy objaw, który powinien zaalarmować pacjenta, to obecność guzka lub zmiana konsystencji jądra. Należy zaznaczyć, iż guz jądra jest wyraźnie twardszy od prawidłowego (dla ułatwienia drugiego zdrowego) jądra. Inny ważny objaw, jaki z łatwością może zaobserwować pacjent, to uczucie ciężaru w mosznie, a następnie powiększenie się moszny, co związane jest z gromadzeniem się płynu wysiękowego. Kolejno pojawić się może ból i dyskomfort. Ból nie jest charakterystyczny w tym schorzeniu, co jest częstym powodem zbyt późnego kontaktu z lekarzem. Do innych objawów, jakie mogą wystąpić, zalicza się np.: nasilenie cech męskich, tj. zwiększenie owłosienia skóry twarzy, wzrost tkanki mięśniowej. Inne z kolei mogą powodować feminizację organizmu (powiększanie się gruczołów piersiowych, podwyższenie wysokości głosu). Częsty brak bolesności i ignorowanie innych symptomów powodują, iż chorzy zgłaszający się do lekarza specjalisty mają już $z$ reguły zaawansowaną chorobę nowotworową. Znamienne jest to, iż rak jądra daje dość szybko przerzuty do płuc czy węzłów chłonnych nadobojczykowych, powodując przez to utrudnienie pełnego wyleczenia [1].

\section{Leczenie}

Metodą z wyboru jest orchidektomia, tzn. chirurgiczne usunięcie zmienionego chorobowo jądra wraz z najądrzem. Rozległość operacji czy również w trakcie operacji decyzja o usunięciu węzłów chłonnych pachwinowych zależą od stopnia rozwoju procesu chorobowego i ostatecznie od samej decyzji lekarza urologa. Dalsze metody leczenia uzupełniającego to: chemioterapia, radioterapia, baczna obserwacja i kontrole w poradni onkologicznej oraz samokontrola. Niektórzy korzystają z protezy jądra, pozwalającej przywrócić pierwotny wygląd moszny, poprawiając przez to jakość życia [9].

\section{Rokowanie i prewencja}

W tym typie schorzenia prewencja ma ogromne znaczenie. Jak wspomniano wcześniej, można w porę zauważyć niepokojące objawy, co spowoduje szybką interwencję urologiczną, której skuteczność wynosi do $100 \%$. U chorych po usunięciu jądra $z$ nasieniakiem w pierwszym stopniu zaawansowania, to jest, gdy choroba jest ograniczona do jądra, rokowanie jest bardzo dobre. Odsetek zgonów nie przekracza 1\% [10]. Ważne również jest ograniczenie możliwości rozwoju choroby w drugim, zdrowym jądrze. Nie bez znaczenia jest również prowadzenie „higieny jąder” - co można rozumieć jako baczne obserwowanie niepokojących objawów, niebagatelizowanie urazów, stanów zapalnych, dbanie o komfort zawartości moszny, tzn. nieprzegrzewanie jej, zakładanie luźnej bielizny. Do najważniejszych czynności, do jakich zachęca się coraz częściej, należy samobadanie jąder, które stanowi podstawową metodę wczesnego rozpoznania choroby nowotworowej. Samobadanie jader zaleca się wykonywać co najmniej raz w miesiącu (najlepiej jeden konkretny dzień, np. dzień urodzin). Technika samobadania jest prosta: polega na przetaczaniu jądra pomiędzy kciukiem a palcem wskazującym od górnego do dolnego bieguna [11]. W przypadku wątpliwości mężczyzna powinien niezwłocznie pojawić się w gabinecie lekarza. 
Jak już wspomniano, podniesienie poziomu stanu wiedzy i wdrożenie działań prewencyjnych leży głównie po stronie lekarzy, pielęgniarek, ale także mediów. Ważna jest też rola innych instytucji mających kontakt z potencjalnymi pacjentami, np. szkół, w tym szkół kształcących przyszłych pracowników ochrony zdrowia.

\section{Cel badań}

Celem niniejszej pracy było zbadanie stanu wiedzy studentów płci męskiej Państwowej Wyższej Szkoły Zawodowej (PWSZ) im. Jana Amosa Komeńskiego w Lesznie na temat raka jądra oraz zwrócenie uwagi na tę chorobę i jej objawy, a także na potrzebę samobadania. Założono, że uzyskane w badaniu wyniki, pozwolą określić, czy istnieje potrzeba edukacji i zwiększania wiedzy o raku jądra.

\section{Materiał i metody \\ Grupa badana}

Badanie miało miejsce w budynku głównym Państwowej Wyższej Szkoły Zawodowej im. Jana Amosa Komeńskiego w Lesznie w trakcie przerwy między zajęciami dydaktycznymi, w dniach 1-31.03.2019 r. PWSZ w Lesznie prowadzi naukę studentów na 14 kierunkach. Posiada 5 Instytutów, w tym Instytut Zdrowia i Kultury Fizycznej, który przygotowuje kandydatów do zawodów: nauczyciela WF ( I, II stopień), fizjoterapeuty - poziom magisterski i pielęgniarki na poziomie licencjatu. Dobór badanej grupy miał charakter dogodnościowy, obejmowała studentów, którzy wyrazili chęć uczestnictwa w ankiecie. Łącznie uzyskano wypełnione kwestionariusze ankiety od 102 osób, z czego dwa odrzucono z uwagi na błędne wypełnienie. Ostatecznie badana grupa liczyła 100 studentów.

\section{Narzędzie badawcze}

Badanie zostało przeprowadzone przy użyciu kwestionariusza ankiety w formie papierowej, przekazanej do wypełnienia respondentom.

Kwestionariusz ankiety zawierał 11 pytań lub stwierdzeń, na które badany mógł odpowiedzieć: „prawda” lub „fałsz”. Przed wypełnieniem kwestionariusza ankiety nie przedstawiono badanym informacji dotyczących raka jądra. Kwestionariusz ankiety miał charakter autorski, opracowany został przez członków Koła naukowego „Medyk” - studentów kierunku pielęgniarstwo PWSZ im. Jana Amosa Komeńskiego w Lesznie.

Poniżej przedstawiono pytania zamieszczone w kwestionariuszu ankiety:

1. Obrzęk $\mathrm{i} /$ lub guz (stwardnienie) w jednym lub obu jądrach to objawy raka jądra.
2. Uczucie ciężkości w mosznie może być objawem raka jądra.

3. Tępy ból lub uczucie ucisku w dolnej części brzucha lub w pachwinie może być objawem raka jądra.

4. Tępe bóle w dolnej części pleców i brzucha mogą być objawami raka jądra.

5. Brak energii to objaw raka jądra.

6. Pocenie się (bez przyczyny) to objaw raka jądra.

7. Krótki oddech, kaszel albo ból w klatce piersiowej to objawy raka jądra.

8. Jedno jądro większe od drugiego to objawy raka jądra.

9. Lekki ból w okolicy najądrza przy nacisku to objawy raka jądra.

10. Występujące w rodzinie (np. ojciec, stryj, brat) przypadki raka jądra mają wpływ na wystąpienie tej choroby u następnych pokoleń.

11. Samobadanie jąder raz w miesiącu to „dobra praktyka odpowiedzialnego mężczyzny”.

Na wszystkie pytania, oprócz 9, odpowiedź brzmi ,prawda”.

\section{Wyniki}

Poniższy wykres przedstawia rozkład procentowy poprawnych i błędnych odpowiedzi na pytania/stwierdzenia dotyczące raka jądra.

Pytania, na które najczęściej udzielano odpowiedzi poprawnych, to: 1, 10 i 11, gdzie odpowiedzi prawidłowe wynosiły odpowiednio $88 \%$, 85\% i $87 \%$. Były to stwierdzenia, które kojarzone są z każdym typem nowotworu (guz lub etiologia genetyczna), a także pytanie o profilaktykę - samobadanie jąder.

Pytania z najmniejszą liczbą odpowiedzi poprawnych to: 5, 6 i 7. Dotyczyły one takich objawów jak: brak energii, pocenie się bez przyczyny oraz krótki oddech, kaszel i ból w klatce piersiowej. Objawy te najczęściej nie są jednoznacznie kojarzone z nowotworami, a często infekcjami górnych dróg oddechowych, przeziębieniem czy zmęczeniem.

Dodatkowo można zauważyć, że nikt z ankietowanych nie uzyskał $100 \%$ poprawnych odpowiedzi na pytania zawarte w kwestionariuszu ankiety. Poprawnych odpowiedzi w 91\%, 82\%, 73\%, 64\%, 55\%, 45\%, 36\%, $25 \%$ i $18 \%$ udzieliło odpowiednio 3, 3, 10, 6, 22, 30, 20, 4 i 1 badany.

Prawie połowa (44\%) badanych studentów uzyskała wynik wyższy niż 50\%, co oznacza, że 56\% uzyskało wynik niższy niż połowa możliwych do uzyskania punktów. 


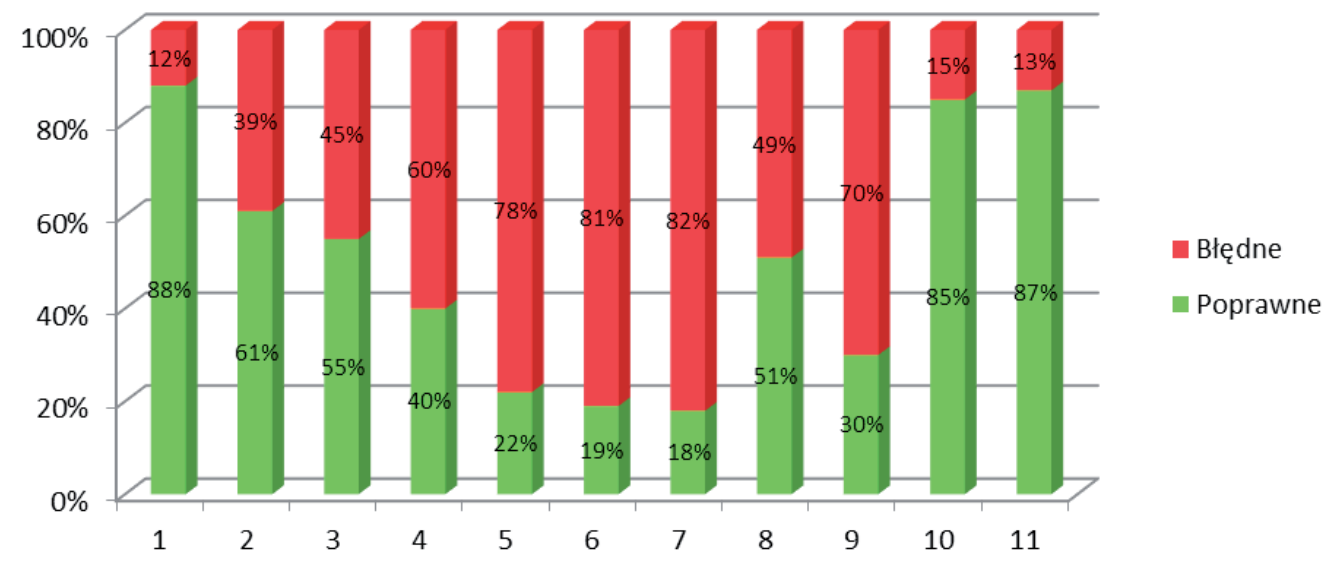

Rycina 1. Rozkład procentowy poprawnych i błędnych odpowiedzi na pytania/stwierdzenia dotyczące raka jądra Figure 1. The percentage of correct and incorrect answers to testicular cancer questions/statements

Źródło: opracowanie własne

Source: author's own research

\section{Podsumowanie}

Badanie przeprowadzone wśród studentów wykazato niedostateczną wiedzę o schorzeniu, jakim jest rak jądra. Prawdopodobnie jest to spowodowane tym, że kampanie edukacyjne na temat raka jądra nie są tak powszechne jak te, które dotyczą na przykład raka piersi czy raka szyjki macicy. Kolejnym czynnikiem może być fałszywe poczucie wstydu podczas rozmowy o męskich narządach płciowych, a tym bardziej o niepokojących objawach z nimi związanych, czy też przyznanie się do choroby tych okolic ciała.

\section{Wnioski}

1. Studenci PWSZ w Lesznie posiadają niski stan wiedzy na temat raka jądra i samobadania jąder.

2. Istnieje potrzeba zwiększenia wiedzy młodzieży na temat raka jądra i samobadania jąder poprzez kampanie edukacyjne.

3. Potrzeba zwiększenia wiedzy na badany temat jest szczególnie ważna w odniesieniu do studentów kierunków medycznych, którzy powinni propagować temat profilaktyki raka jąder wśród przyszłych pacjentów.

\section{Piśmiennictwo}

1. Pawlicki M, Legutko J. Zarys diagnostyki nowotoworów złośliwych oraz opieki w trakcie i po leczeniu onkologicznym. Bielsko Biała. Alfa Medica Press; 2013.146-149.

2. Wardle J, Steptoe A, Burckhardt R, Vögele C, Vila J, Zarczynski Z. Testicular self-examination: Attitudes and practices among young men in Europe. Preventive Medicine: An International Journal Devoted to Practice and Theory, 1994; 23(2): 206-210.

3. Daley CM. College men's knowledge, attitudes, and beliefs about testicular cancer, Am J Mens Health. 2007; 1(3): 173-82. doi: $10.1177 / 1557988306293770$.
4. Moore RA, Topping A. Young men's knowledge of testicular cancer and testicular self-examination: a lost opportunity? Eur J Cancer Care. 1999 Sep; 8(3):137-42.

5. Muliira JK, Nalwanga PB, Muliira RS, Nankinga Z. Knowledge, perceived risk and barriers to testicular self-examination among male university students in Uganda. J. Men's Health. 2012; 9(1): 36-44.

6. Ward KD, Vander Weg MW, Read MC, Sell MA, Beech BM. Testicular cancer awareness and self-examination among adolescent males in a community-based youth organization. Prev. Med. 2005; 41(2): 386-398.

7. Baran M, Walewska E, Binko K, Ścisło L, Szczepanik A, Czupryna A. Young men's knowledge on testicular cancer. Nursing Problems. 2014; 22(1): 1-5.

8. Piróg M, Padała O, Podgórniak M, Putowski M, Sadowska M, Wdowiak A. Świadomość nowotworu jądra wśród młodych mężczyzn na Lubelszczyźnie, Pielęgniarstwo XXI wieku, 2016; 15, 2(18-25).

9. Zieliński T. Protezy jąder - rodzaje, zastosowanie, wyniki. Przegl. Urol. 2009; 1(53) (20 08 2019).

10. Krajowy Rejestr Nowotworów. http://onkologia.org.pl/rakjadra/. [20. 08. 2019].

11. Gośliński J, Rak jadra, objawy, leczenie i rokowania. https:// www.zwrotnikraka.pl/rak-jadra-objawy-leczenie [20.08.2019].

12. Hau, Chen C, M.S.N. California State University, Beliefs of nurse practitioner students toward testicular cancer and teaching testicular self-examinations. 2012; 69.

Artykuł przyjęty do redakcji: 17.04.2020.

Artykuł przyjęty do publikacji: 05.10.2020.

Źródło finansowania: Praca nie jest finansowana z żadnego źródła. Konflikt interesów: Autorzy deklarują brak konfliktu interesów.
Adres do korespondencji:
Maciej Górecki
ul. Mickiewicza 5
64-100 Leszno
Zakład Pielęgniarstwa, Instytut Zdrowia i Kultury Fizycznej, Państwowa Wyższa Szkoła Zawodowa im. Jana Amosa Komeńskiego 